\title{
A note on the influence of fat supplementation of sheep rations on the level of purine derivatives in urine and bacterial synthesis in the rumen*
}

\author{
A. Potkański ${ }^{1}$, M. Szumacher-Strabel ${ }^{1}$, J. Kowalczyk ${ }^{2}$ \\ and A. Cieślak ${ }^{{ }^{* *}}$ \\ ${ }^{1}$ August Cieszkowski Agricultural University, \\ Department of Animal Nutrition and Feed Management \\ Wolyńska 33, 60-637 Poznań, Poland \\ ${ }^{2}$ The Kielanowski Institute of Animal Physiology and Nutrition, \\ Polish Academy of Sciences \\ 05-110 Jabłonna, Poland
}

(Received 4 November 2002; accepted 20 December 2002)

\begin{abstract}
The effect of different types of fat supplementation on the level of purine derivatives in urine and bacterial protein synthesis in the rumen was estimated on four rams in a $4 \times 4$ Latin square design with four experimental diets differing in the percentage of supplemented fat. The basic ration for the control group consisted of meadow hay and concentrate (60:40) and was supplemented for experimental groups with rape seed oil, hydrogenated rape seed oil or linseed oil at a level of 0 (control), 4, 8 and 10\% in dry matter. Allantoin excretion in urine was used as a marker for estimation of microbial protein synthesis. Bacterial protein synthesis declined $(\mathrm{P}<0.05)$ in response to an increased concentration of rape seed or linseed oil in the diet. Hydrogenated rape seed oil had no influence on either microbial protein synthesis in the rumen or on the level of purine derivatives in urine. The allantoin level in urine and hence bacterial synthesis in the rumen decreased when 8 and $10 \%$ of rape seed oil was added to the ration. The level of uric acid, hypoxanthine and xanthine in urine was unaffected by the type of added fat.
\end{abstract}

KEY WORDS: fat, bacterial protein synthesis, purine derivatives, allantoin, rumen, sheep

* Supported by the State Committee for Scientific Research, Grant No. 5 P06E 02516

** Supported by the Foundation for Polish Science (FNP) 


\section{INTRODUCTION}

Bacterial synthesis in the rumen is one of the basic parameters that characterizes rumen metabolism and signalizes changes caused by diet manipulation. One of the reasons for manipulating diet composition is the energy deficit in rations for high producing ruminants. The use of fats as an energy source in cow and sheep rations has been the focus of interest for years (Murphy et al., 1987). Although the addition of large amounts (up to 10\%) of lipids to the diet of ruminants with high production potential satisfies the animals' considerable energy requirements, it can cause changes in rumen metabolism (Jouany, 1994), mostly in microbial protein synthesis. The efficiency of microbial synthesis depends on the nature of fatty acids and increases particularly when ruminal digestibility of organic matter is depressed (Doreau and Ferlay, 1995).

The objective of the current study was to determine the effect of different fats added to ruminant rations on bacterial protein synthesis in the rumen of sheep.

\section{MATERIAL AND METHODS}

\section{Animals and diets}

The experiments were carried out on four rams of $40 \pm 5 \mathrm{~kg}$ body weight in a $4 \mathrm{x} 4$ Latin square design to determine the effect of different fat sources on rumen bacterial synthesis measured by a non-invasive method based on purine derivative excretion in urine. The experiment consisted of four 16-day trials, 14 days of adaptation to the diet and 2 days of sample collection. The basic ration for the control group consisted of meadow hay and concentrate (60:40); for the experimental groups the ration was supplemented with rape seed oil, hydrogenated rape seed oil, or linseed oil at a level of 0 (control), 4,8 and $10 \%$ in dry matter of the diet. The energy value of the rations was $5.06 \mathrm{MJ} \mathrm{EN} / \mathrm{kg}$, whereas the crude protein content was $118 \mathrm{~g} / \mathrm{kg}$. The daily ration was divided into two equal portions and fed at 08.00 and $18.00 \mathrm{~h}$. Drinking water was available ad libitum throughout the experiment.

\section{Sampling and analysis}

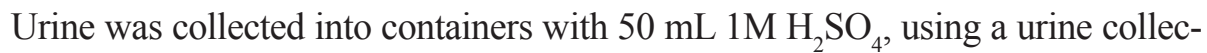
tion device according to Kowalczyk et al. (1996). Samples (about $30 \mathrm{~mL}$ ) were frozen and then the purine derivatives were measured. Purine concentrations in urine were determined by a modified HPLC method of Ballcels et al. (1992). Urinary allantoin excretion was used as a marker for estimation of bacterial protein synthesis, which was calculated according to the equation of Puchała and Kulasek (1992). 


\section{Statistical analysis}

All data were analyzed using SAS procedures (User's Guide, 1990).

\section{RESULTS}

Feeding fat to sheep rations caused some changes in the extent of bacterial protein synthesis in the rumen. Bacterial synthesis declined significantly $(\mathrm{P}<0.05)$ in response to increase rape seed (Table 1) or linseed oil (Table 2) concentration in the diet. Hydrogenated rape seed oil had no influence on either the level of purine derivatives in urine or bacterial synthesis in the rumen (Table 3). The allantoin level in urine and hence bacterial synthesis in the rumen decreased when 8 and $10 \%$ rape seed oil was added to the ration. The level of allantoin decreased from $691 \mathrm{mg} \mathrm{N} \mathrm{d}^{-1}$ in the control group to 76 and $244 \mathrm{mg} \mathrm{N} \mathrm{d}^{-1}$, respectively when 8 and $10 \%$ of rape seed oil was added to the ration. We also observed a slight, but not statistically significant, drop in the allantoin level when $4 \%$ rape seed oil was added. These changes are in line with the extent of bacterial protein synthesis in the rumen, which decreased with fat addition as compared with the control group. Bacterial protein synthesis decreased $(\mathrm{P}<0.05)$ when the diet was supplemented with rape seed oil from 15.4 in control group to 1.9 and $5.4 \mathrm{mg} \mathrm{N} \mathrm{d}^{-1}$, respectively when 8 and $10 \%$ rape seed oil was added (Table 1). Bacterial synthesis in the rumen of sheep fed $4 \%$ rape seed oil in the diet was also reduced, but the differences were not significant $(\mathrm{P}>0.05)$. Similarly, in the case of linseed oil addition, the allantoin level decreased when the fat concentration in the diet increased. When the ration contained 8 or $10 \%$ linseed oil, the level of allantoin decreased from $498 \mathrm{mg} \mathrm{N} \mathrm{d}^{-1}$ in the control group to 234 and $398 \mathrm{mg} \mathrm{N} \mathrm{d}^{-1}$, respectively. The extent of bacterial synthesis was also reduced by adding 8 and $10 \%$ linseed oil and reached 5.2 and $8.8 \mathrm{mg} \mathrm{N} \mathrm{d}^{-1}$ in comparison with the control group $\left(11.1 \mathrm{mg} \mathrm{N} \mathrm{d}^{-1}\right)$. The level of uric acid, hypoxanthine and xanthine in urine was unaffected by the type of added fat.

TABLE 1

Effect of rape seed oil on the extent of bacterial synthesis in rumen of sheep

\begin{tabular}{lcccc}
\hline & \multicolumn{4}{c}{ Rape seed oil in diet, \% } \\
\cline { 2 - 5 } & 0 & 4 & 8 & 10 \\
\hline Bacterial N, g d & $15.4^{\mathrm{a}}$ & $7.9^{\mathrm{a}}$ & $1.9^{\mathrm{b}}$ & $5.4^{\mathrm{b}}$ \\
Allantoin, $\mathrm{mg} \mathrm{N} \mathrm{d}^{-1}$ & $691^{\mathrm{a}}$ & $354^{\mathrm{a}}$ & $76^{\mathrm{b}}$ & $244^{\mathrm{b}}$ \\
Uric acid, mg N d $^{-1}$ & 53.8 & 42.1 & 12.5 & 55.5 \\
Hypoxanthine and & 24.9 & 13.2 & 4.3 & 4.1 \\
$\quad$ xanthine, $\mathrm{mg} \mathrm{N} \mathrm{d}^{-1}$ & & & \\
\hline
\end{tabular}

a,b means in rows with the same letter are not significantly different at $\mathrm{P}<0.05$ 
Effect of linseed oil on the extent of bacterial synthesis in rumen of sheep

\begin{tabular}{lcccc}
\hline & \multicolumn{4}{c}{ Linseed oil in diet, \% } \\
\cline { 2 - 5 } & 0 & 4 & 8 & 10 \\
\hline Bacterial N, g d $^{-1}$ & $11.1^{\mathrm{a}}$ & $10.7^{\mathrm{a}}$ & $5.2^{\mathrm{b}}$ & $8.8^{\mathrm{b}}$ \\
Allantoin, $\mathrm{m} \mathrm{N} \mathrm{d}^{-1}$ & $498^{\mathrm{a}}$ & $479^{\mathrm{a}}$ & $234^{\mathrm{b}}$ & $398^{\mathrm{ab}}$ \\
Uric acid, mg N d & 66.0 & 88.8 & 50.5 & 584 \\
Hypoxanthine and & 18.8 & 25.2 & 11.0 & 21.8 \\
$\quad$ xanthine, m N d $^{-1}$ & 18.8 & &
\end{tabular}

a,b means in rows with the same letter are not significantly different at $\mathrm{P}<0.05$

TABLE 3

Effect of hydrogenated rape seed oil on the extent of bacterial synthesis in rumen of sheep

\begin{tabular}{lcccc}
\hline & \multicolumn{4}{c}{ Hydrogenated rape seed oil in diet, \% } \\
\cline { 2 - 5 } & 0 & 4 & 8 & 10 \\
\hline Bacterial N, d $^{-1}$ & 13.2 & 13.0 & 9.3 & 11.4 \\
Allantoin, $\mathrm{mg} \mathrm{N} \mathrm{d}^{-1}$ & 593 & 585 & 420 & 514 \\
Uric acid, mg N d$^{-1}$ & 63.1 & 50.8 & 52.5 & 60.8 \\
Hypoxanthine and & 7.1 & 4.2 & 4.4 & 9.0 \\
$\quad$ xanthine, $\mathrm{mg} \mathrm{N} \mathrm{d}^{-1}$ & & & & \\
\hline
\end{tabular}

\section{DISCUSSION}

The proportion of individual purine derivatives in the urine of sheep, as a percentage of their sum, in our experiments was similar to that reported by Chen and Gomez (1992): allantoin $60-80 \%$, uric acid 30-10\%, xanthine plus hypoxanthine 10-5\%; individual values of allantoin recovery varied from 66 to $95 \%$ (Prasitkusol et al., 2002). High variability within the values for individual purine fractions is caused by numerous factors as species, breed, diversity of particular animals (Dewhurst et al., 2000; Prasitkusol et al., 2002).

The extent of bacterial protein synthesis calculated on the basis of allantoin excretion, expressed as grams of microbial $\mathrm{N}$ per day, was significantly lower when 8 or $10 \%$ of rape seed and linseed oil was added to the sheep ration. Eight per cent of added fat, similarly as in our previous experiments (Szumacher-Strabel, 1998), had a much more detrimental effect on the allantoin level and hence microbial synthesis, than $10 \%$ of added fat in the sheep ration, which is rather difficult to explain on the basis of the obtained results. The usually positive effect of fat on bacterial synthesis was found when the level of fat added as a source of additional energy to high-producing animals did not exceed $4 \%$ in dry matter. It is known that fatty acids, particularly unsaturated ones, have a direct inhibitory effect on the rumen microbial population (Broudiscou et al., 1990). According to 
Jouany (1994) unsaturated fatty acids are particularly active against protozoa and, if present in large quantities, may even defaunate the rumen. This could probably explain the beneficial effect of moderate quantities of lipids on microbial protein synthesis. In the present experiments under hydrogenated rape seed oil treatment there were no changes in the level of purine derivatives or extent of bacterial protein synthesis. Hydrogenated rape seed oil, as a source of mostly saturated fatty acids, did not interact with bacterial populations (Table 3). Also according to Doreau and Ferlay (1995) the efficiency of microbial synthesis depends on the nature of fatty acids, what can be related to the decrease in protozoa number in the rumen. High amounts of rape seed and linseed oils, sources of mono- and polyunsaturated fatty acids, resulted in depression of the allantoin level and extent of bacterial synthesis.

The results of our experiments allow us to assume that supplemental fat in sheep rations in amounts not exceeding about $4 \%$ in dry matter has no detrimental effect on excretion of purine derivatives in urine or bacterial synthesis in the rumen, whereas 8 and $10 \%$ of fat rich in mono- or polyunsaturated fatty acids, can decrease bacterial synthesis in the rumen of sheep.

\section{REFERENCES}

Ballcels J., Guada J.A., Peiro J.M., 1992. Simultaneous determination of allantoin and oxypurines in biological fluids by high-performance liquid chromatography. J. Chromatogr. 575, 153-157

Broudiscou L., Van Nevel C.J., Demeyer D.I., 1990. Effect of soya oil hydrolysate on rumen digestion in defaunated and refaunated sheep. Anim. Feed Sci. Tech. 30, 51-67

Chen X.B., Gomes M.J., 1992. Estimation of microbial protein supply to sheep and cattle based on urinary excretion of purine derivatives - an overview of the technical details. International Feed Resources Unit, Rowett Research Institute, Bucksburn (UK). Occasional Publication

Dewhurst R.J., Davies D.R., Merry R.J., 2000. Microbial protein supply from the rumen. Anim. Feed Sci. Tech. 85, 1-21

Doreau M., Ferlay A., 1995. Effect of dietary lipids on nitrogen metabolism in the rumen: a review. Livest. Prod. Sci. 43, 97-110

Jouany J.P., 1994. Methods of manipulating the microbial metabolism in the rumen. Ann. Zootech. $43,49-62$

Kowalczyk J., Skiba B., Buczkowski Z., Kowalik B., 1996. A device for quantitative urine collection from male sheep in balance trials. J. Anim. Feed Sci. 5, 297-301

Murphy M., Uden P., Palmquist D.L., Wiktorsson H., 1987. Rumen and total diet digestibilities in lactating cows fed diets containing full-fat rapeseed. J. Dairy Sci. 70, 1572-1582

Prasitkusol P., Ørskov E.R., Chen X.B., Hovell F.D.D., Kyle D.J., 2002. Variation between sheep in renal excretion of allantoin. Brit. J. Nutr. 87, 561-568

Puchała R., Kulasek G.W., 1992. Estimation of microbial protein flow from the rumen of sheep using microbial nucleic acid and urinary excretion of purine derivatives. Can. J. Anim. Sci. 72, $821-830$ 
SAS, 1990. SAS/STAT Users guide (Release 6.03). SAS Institute Inc., Cary, NC (USA)

Szumacher-Strabel M., 1998. Microbial protein net synthesis in sheep fed hay-concentrate diets supplemented with different source and level of fat. J. Anim. Feed Sci. 7, 395-404

\section{STRESZCZENIE}

\section{Wplyw dodanego tluszczu do dawek dla owiec na poziom pochodnych purynowych w moczu i rozmiar syntezy białka w żwaczu}

Celem przeprowadzonych doświadczeń było określenie wpływu rodzaju i ilości dodanego tłuszczu do dawek składających się z siana i mieszanki treściwej (60:40\%) na poziom pochodnych purynowych w moczu oraz rozmiar syntezy białka w żwaczu. Doświadczenia przeprowadzono na czterech trykach w układzie kwadratu łacińskiego 4 x 4 . Do dawki kontrolnej dodano tłuszcze pochodzenia roślinnego, różniące się zawartością długołańcuchowych kwasów tłuszczowych: olej rzepakowy, uwodorniony olej rzepakowy lub olej lniany w ilości 0 (grupa kontrolna), 4, 8 lub 10\% suchej masy paszy. W pobranych próbach moczu określono poziom pochodnych purynowych: alantoiny, kwasu moczowego, hipoksantyny i ksantyny. Stwierdzono statystycznie istotne zmiany $(\mathrm{P}<0.05) \mathrm{w}$ rozmiarze syntezy białka mikroorganizmów u zwierząt żywionych dawkami z udziałem oleju rzepakowego i lnianego. Dodatek 8 i 10\% oleju rzepakowego i lnianego do dawki obniżył poziom alantoiny w moczu, a tym samym rozmiar syntezy białka mikroorganizmów. Uwodorowany olej rzepakowy nie miał wpływu ani na poziom pochodnych purynowych ani na rozmiar syntezy białka mikroorganizmów. 